\title{
Effects of Co-culturing with Live and Autoclaved Bacillus subtilis on Antagonistic Activity of Marine Fungi against Plant Pathogens
}

\author{
Unchalee Mokkala and Tida Dethoup*
}

Department of Plant Pathology, Faculty of Agriculture, Kasetsart University, Bangkok - 10900, Thailand.

\begin{abstract}
The co-culturing of the fungi with Bacillus subtilis resulted in increased antifungal activity of Eurotium chevalieri and Emericella foveolata extracts but decreased the effects of Talaromyces tratensis and T. stipitatus extracts. Meanwhile, the co-culturing of marine-derived fungi with autoclaved $B$. subtilis resulted in decreased antifungal activity of $E$. foveolata, $T$. stipitatus and $T$. tratensis but slightly increased activity of $E$. chevalieri. A significant effect of the co-culture of $E$. chevalieri and $B$. subtilis resulted in an increased antifungal activity compared to the axenic cultures with complete inhibition of mycelial growth of all the plant pathogens tested, whereas the extract from fungus alone displayed percentage inhibition ranging from $33.11-100 \%$ at $10 \mathrm{~g} \mathrm{~L}^{-1}$ concentration. Overall, the effect of coculturing with live or autoclaved $B$. subtilis had positive, negative or no effect on the antifungal activities of the tested marine-derive fungi against plant pathogens in vitro.
\end{abstract}

Keywords: Microbial co-cultivation, dual induction, fungal metabolites, antagonistic activity, plant pathogens

*Correspondence: agrtdd@ku.ac.th; +66 2 5761026,

(Received: March 28, 2020; accepted: June 12, 2020)

Citation: Mokkala U, Dethoup T. Effects of Co-culturing with Live and Autoclaved Bacillus subtilis on Antagonistic Activity of Marine Fungi against Plant Pathogens. J Pure Appl Microbiol. 2020;14(2):1245-1254. doi: 10.22207/JPAM.14.2.19

(C) The Author(s) 2020. Open Access. This article is distributed under the terms of the Creative Commons Attribution 4.0 International License which permits unrestricted use, sharing, distribution, and reproduction in any medium, provided you give appropriate credit to the original author(s) and the source, provide a link to the Creative Commons license, and indicate if changes were made. 


\section{INTRODUCTION}

Microorganisms have been proved to be one of most important sources for bioactive metabolites useful for pharmaceutical, industrial and agrochemical applications (Wakefield et al., 2017). The compounds produced by microorganisms in an interaction known as antibiosis are a defense mechanism against other microorganisms competing for space, nutrients, and other resources in natural habitats (Netzker et al., 2015; Oppong-Danquah et al., 2018). In a microbial environment, microorganisms living in close proximity interact with each other via chemical communication pathways resulting in mutualistic, synergistic or antagonistic interactions (Shtark et al., 2012; Ghorchiani et al., 2018; Tomm et al., 2019). Many reports of antibiosis have been recorded in which antagonist microorganisms exert antagonistic actions on plant pathogens (Zhang et al., 2013; Akone et al., 2016).

During the past few decades, co-culturing of either fungus and fungus or fungus and bacterium has been shown to be a method that stimulates the regulatory systems by activation of the silent biosynthesis of a broad diversity of bioactive metabolites and also enhances production of constitutive fungal compounds which are not isolated in axenic cultures in vitro (Ola et al., 2013, Liu et al., 2017; Wakefield et al., 2017; Kamdem et al., 2018; Qadir et al., 2018; Tomm et al., 2019). The co-culturing of different microorganisms from various habitats has been intensively studied in many media to investigate the production of unexplored bioactive metabolites, enzymes or other constituents (Ola et al., 2013; Moussa et al., 2020). Most reports are concerned with studies of the co-culturing of live microorganisms. For instance, Serrano et al., (2017) reported that the co-culturing as a dual culture of fungal strains and a plant pathogenic fungus, Botrytis cinerea triggered the production of new bioactive compounds that suppressed the mycelial growth of the test plant pathogens, Colletotrichum acutatum, Fusarium proliferatum and Magnaporthe grisea and the human pathogens, Candida albicans and Aspergillus fumigatus. There is only one report concerned with the effect of co-cultivation of a fungus and an autoclaved bacterium (Ancheeva et al., 2017).
Microorganisms from marine environments have also been reported as a great source of bioactive compounds which are not only useful in pharmaceutical applications but also have proved to be promising biological control agents for plant protection (Dethoup et al., 2018). Many previous reports showed the antagonistic activity of marine microorganisms against many plant pathogens of economically important crops (Rongbian et al., 2009; Manilal et al., 2010; Shen et al., 2014; Dethoup et al., 2015). Our group reported the marine fungus, Talaromyces tratensis KUFA 0091 in controlling rice diseases in plants and fruit rot in mango (Dethoup et al., 2018; Suasa-ard et al., 2019). Moreover, during the study of bioactive metabolites from marine fungi collected from Thai waters, our research group has isolated novel secondary metabolites, some of which possessed either cytotoxic or antimicrobial activities (Kumla et al., 2014; 2017; Buttachon et al., 2016).

To date, application of fungicides is still the convenient approach for crop protection. However, their residues and toxicity affect human and animal health as well as the environment (Rizzati et al., 2016; Holka, 2017; Brasil et al., 2018; Turull et al., 2018). Biological control agents (BCAs) present an attractive alternative to fungicides. However, the screening of antagonistic activities of microorganisms from various habitats requires time to assess their potential in planta (Terao et al., 2017; El-Mougy \& Abdel-Kader, 2018).

Thus, the co-culturing of marine microorganisms might be a promising approach to combat plant diseases. Studies about the impacts of the co-culturing of marine fungi and marine bacteria against plant pathogens are still limited. Recently, Oppong-Danquah et al., (2018) found that plant pathogens triggered chemical signals in selected marine fungi resulting in production of novel metabolites and increased the production of compounds in co-cultures although no enhanced antagonistic activity against plant pathogens were reported.

The objectives of this study was to determine the effect of the co-culturing of both live and dead cells of a marine-derived bacterium, B. subtilis, with five marine-derived fungi on the dynamics of their antagonistic activity against plant pathogens in vitro. 


\section{MATERIALS AND METHODS Fungal and bacterial strains}

The marine-derived fungi and bacterium used in this study were isolated from marine sponges collected at different coral reefs at Chonburi and Phang Nga provinces during April 2010 - February 2015 as shown in Table 1. The sponge samples were collected by SCUBA diving and kept in plastic bags with sea water. The isolation of the fungi from marine sponge samples was conducted as described previously by Dethoup et al., (2015).

For isolation of the bacterium, sponge samples were surface sterilized and cut into small pieces. After drying on sterile filter papers, the samples were mashed in a sterile mortar and pestle. After this, sponge sap was collected with a sterile loop, cultured on nutrient agar (NA), and incubated at room temperature for 2 days. The single bacterial colony was sub cultured onto NA slants for further identification.

Identification of the Fungi and the Bacterium

The marine fungi were identified using ITS primers, ITS1 and ITS4 (White et al., 1990). DNA was extracted from young mycelia obtained from 3-day-old colonies (Murray \& Thompson, 1980). PCR reactions were performed on a thermal cycler as described previously by Dethoup et al., (2016) and the accession numbers of their ITS gene sequences are shown in Table 1.

The isolated bacterium was cultured in nutrient broth on a rotary shaker at $120 \mathrm{rpm}$ for $24 \mathrm{~h}$, and then, $1 \mathrm{~mL}$ of culture broth was collected and put into a micro tube $(1.5 \mathrm{~mL})$ and centrifuged at $13,500 \mathrm{rpm}$ for $10 \mathrm{~min}$. The bacterial cells were kept, and the DNA was extracted following a modified Murray and Thompson method (Murray and Thompson, 1980). Primer pairs fD1 and rP2
(Weisburg et al., 1991) were used for 16S rDNA gene amplification. PCR reactions were performed on a thermal cycler as described previously (Dethoup et al., 2016).

\section{Metabolite Extraction}

The individual fungal metabolite extraction was conducted as described previously (Dethoup et al., 2016).

\section{Fungus- $B$. subtilis co-culturing}

The $B$. subtilis was cultured on NA for 3 days by the streak method and a single colony was transferred into $10 \mathrm{~mL}$ of NB in a test tube and incubated on a rotary shaker for 2 days at $28^{\circ} \mathrm{C}$. Each fungus was cultured in solid rice in a flask as described above for 10 days. Then, each fungal culture was inoculated with $10 \mathrm{~mL}$ of bacterial broth per flask and incubated further for 20 days at $28^{\circ} \mathrm{C}$. After this, ethyl acetate $(500 \mathrm{~mL})$ was poured to each flask, macerated for 7 days and then filtered. The filtrate was evaporated using rotary evaporator to furnish the crude extracts of each fungus- $B$. subtilis co-culture crude extract.

\section{Fungus- autoclaved $B$. subtilis co-culturing}

A single 3 day-old colony of $B$. subtilis was cultured in $10 \mathrm{~mL}$ of NB in a test tube, incubated on rotary shaker for 2 days at $28^{\circ} \mathrm{C}$, and then autoclaved at $121^{\circ} \mathrm{C}$ for $15 \mathrm{~min}$. Each fungus was cultured in solid rice in a flask as described above for 10 days, then inoculated with $10 \mathrm{~mL}$ of autoclaved bacterial broth per flask, and then incubated further for 20 days at $28^{\circ} \mathrm{C}$. The crude extract of each fungus-autoclaved $B$. subtilis coculture, was obtained as described above with ethyl acetate.

Evaluation of single culture and co-culture extracts against plant pathogenic fungi

The antifungal activity of the ethyl acetate crude extract of fungal single culture and

Table 1. Marine-derived fungi and bacterium used in this study

\begin{tabular}{lllll}
\hline $\begin{array}{l}\text { Marine sponge-associated } \\
\text { fungus/ bacterium }\end{array}$ & KUFA & $\begin{array}{l}\text { Accession } \\
\text { No. }\end{array}$ & Marine sponge & Location \\
\hline $\begin{array}{l}\text { Eurotium chevalieri } \\
\text { Emericella foveolata }\end{array}$ & 0464 & KY942148 & Rhabdermia sp. & Similan Island, Phang Nga \\
Myrothecium verrucaria & 0991 & KY041869 & Xestospongia testudinaria & Samaesan Island, Chonburi \\
Talaromyces tratensis & 0091 & KT728350 & Xestospongia testudinaria & Samaesan Island, Chonburi \\
Talaromyces stipitatus & 0207 & KU500028 & Stylissa flabelliformis & Samaesan Island, Chonburi \\
Bacillus subtilis & 0097 & MH992142 & Mycale sp. & Samaesan Island, Chonburi \\
& & & & Samaesan Island, Chonburi
\end{tabular}


co cultures with either $B$. subtilis or autoclaved $B$. subtilis was determined using the dilution plate method against ten economically important plant pathogenic fungi in vitro (Table 2) as described previously by Dethoup et al., (2015). Each plant pathogen was identified by molecular techniques and submitted into the Genbank (Table 2). They were maintained on PDA for 7 days before evaluation. The antagonistic activity of each extract against plant pathogen was evaluated using dilution plant method at the final concentrations of 1 and $10 \mathrm{~g} \mathrm{~L}^{-1}$ and then calculated as the percentage of inhibition (Dethoup et al., 2018). Each treatment was conducted with five plates (replications) and separately repeated three times.

\section{RESULTS}

Effects of crude extracts of the marine fungi cultured alone and co-cultured with either live or dead cells of $B$. subtilis against plant pathogenic fungi

Eurotium chevaleri (KUFA 0464)

At the highest tested concentration (10 $\mathrm{g} \mathrm{L}^{-1}$ ) of $E$. chevalieri crude extract from a solitary culture displayed complete mycelial growth inhibition against $R$. solani and showed moderate antagonistic activity against $A$. brassicicola, $P$. palmivora and S. rolfsii with 88.61-95.11\% mycelial growth inhibition (Fig. 1A). However, the crude extract showed moderate inhibition against $P$. palmivora, with $76.67 \%$ mycelial growth inhibition at $1 \mathrm{~g} \mathrm{~L}^{-1}$. Meanwhile, at $1 \mathrm{~g} \mathrm{~L}^{-1}$, the crude extract from the co-culture showed a higher inhibitory activity against the tested plant pathogens than E. chevalieri extract from solitary culture against the mycelial growth of six pathogens (Fig. 2A).

Table 2. Plant pathogenic fungi used in this study

\begin{tabular}{ll}
\hline Plant Pathogenic fungus & Accession number \\
\hline Alternaria brassicicola & $\mathrm{MH749465}$ \\
Bipolaris oryzae & $\mathrm{MG} 914430$ \\
Colletotrichum capsici & $\mathrm{MH749466}$ \\
Colletotrichum gloeosporioides & $\mathrm{MK} 271274$ \\
Fusarium oxysporum & $\mathrm{MK} 271275$ \\
Lasiodiplodia theobromae & $\mathrm{MH724312}$ \\
Phytophthora palmivora & $\mathrm{MH749467}$ \\
Pyricularia oryzae & $\mathrm{MH749468}$ \\
Rhizoctonia solani & $\mathrm{MH749469}$ \\
Sclerotium rolfsii & $\mathrm{MH} 749470$
\end{tabular}

Moreover, the extract obtained from co-culturing with $B$. subtilis increased the antifungal activity against all plant pathogenic fungi except on $B$. oryzae that caused a complete mycelial growth inhibition at $10 \mathrm{~g} \mathrm{~L}^{-1}$ (Fig. $1 \mathrm{~A}$ ).

Meanwhile, the crude extract obtained from the co-culturing of the marine-derived fungus with autoclaved $B$. subtilis also exhibited higher inhibition against all plant pathogens except for $C$. gloeosporiodes at $10 \mathrm{~g} \mathrm{~L}^{-1}$ than the crude extract from solitary culture (Fig. 1A). However, at $1 \mathrm{~g} \mathrm{~L}^{-1}$, the extract showed a lower activity against the plant pathogens than the activity of $E$. chevalieri extract (Fig. 2A).

\section{Emericella foveolata (KUFA 1003)}

Emericella foveolata crude extract displayed a great inhibitory effect against tested plant pathogenic fungi at $10 \mathrm{~g} \mathrm{~L}^{-1}$. Inhibition of mycelial growth remained effective even at $1 \mathrm{~g} \mathrm{~L}^{-1}$, causing more than $50 \%$ mycelial growth inhibition of six out of the 10 plant pathogenic fungi tested (Fig. 2B). The co-culturing of the E. foveolata and live $B$. subtilis extract resulted in increasing the antifungal activity against seven of the tested plant pathogens but showed lower inhibition against F. oxysporum, P. palmivora and $R$. solani than $E$. foveolata crude extract from solitary culture at 1 $\mathrm{g} \mathrm{L}^{-1}$ (Fig. 2B).

The crude extract obtained from coculturing the fungus and autoclaved $B$. subtilis exhibited higher inhibitory activity toward four of the plant pathogens and showed lower activity against five plant pathogens at $1 \mathrm{~g} \mathrm{~L}^{-1}$ when compared with $E$. foveolata crude extract from solitary culture. Moreover, the extract showed lower antifungal activity against $B$. oryzae and $R$. solani than $E$. foveolata crude extract from solitary culture at $10 \mathrm{~g} \mathrm{~L}^{-1}$ (Fig. 1B).

\section{Myrothecium verrucaria (KUFA 0991)}

The results of the antifungal evaluation of $M$. verrucaria crude extract revealed a potent antifungal activity in inhibiting all the plant pathogens at $10 \mathrm{~g} \mathrm{~L}^{-1}$ (Fig. 1C). This extract showed strong activity against all tested plant pathogens except for F. oxysporum but showed low activity at $1 \mathrm{~g} \mathrm{~L}^{-1}$, causing $42 \%$ and $44.44 \%$ inhibition against P. palmivora and $R$. oryzae, respectively (Fig. 2C). The crude extract from the co-culturing of the $M$. verrucaria and $B$. subtilis crude extract exhibited a slightly higher activity against $P$. palmivora, $S$. 
rolfsii and $R$. oryzae at $1 \mathrm{~g} \mathrm{~L}^{-1}$ compared to $M$. verrucaria crude extract and caused complete mycelial growth inhibition of all plant pathogens at $10 \mathrm{~g} \mathrm{~L}^{-1}$, same as the effect of $M$. verrucaria solitary culture crude extract.

The crude extract obtained from the coculturing of the fungus and autoclaved $B$. subtilis exhibited the antifungal activity similar to that of the extract from co-culturing of the $M$. verrucaria and non-autoclaved $B$. subtilis, which caused complete mycelial growth inhibition of all plant pathogens at $10 \mathrm{~g} \mathrm{~L}^{-1}$ (Fig. 1C). However, at $1 \mathrm{~g} \mathrm{~L}^{-1}$, the extract from co-culturing of the $M$. verrucaria and autoclaved $B$. subtilis exhibited higher antifungal activity against $B$. oryzae, P. palmivora, and $S$. rolfsii when compared with the effect $M$. verrucaria solitary culture crude extract but showed lower activity against $R$. oryzae mycelial growth at the same concentration (Fig. 2C).
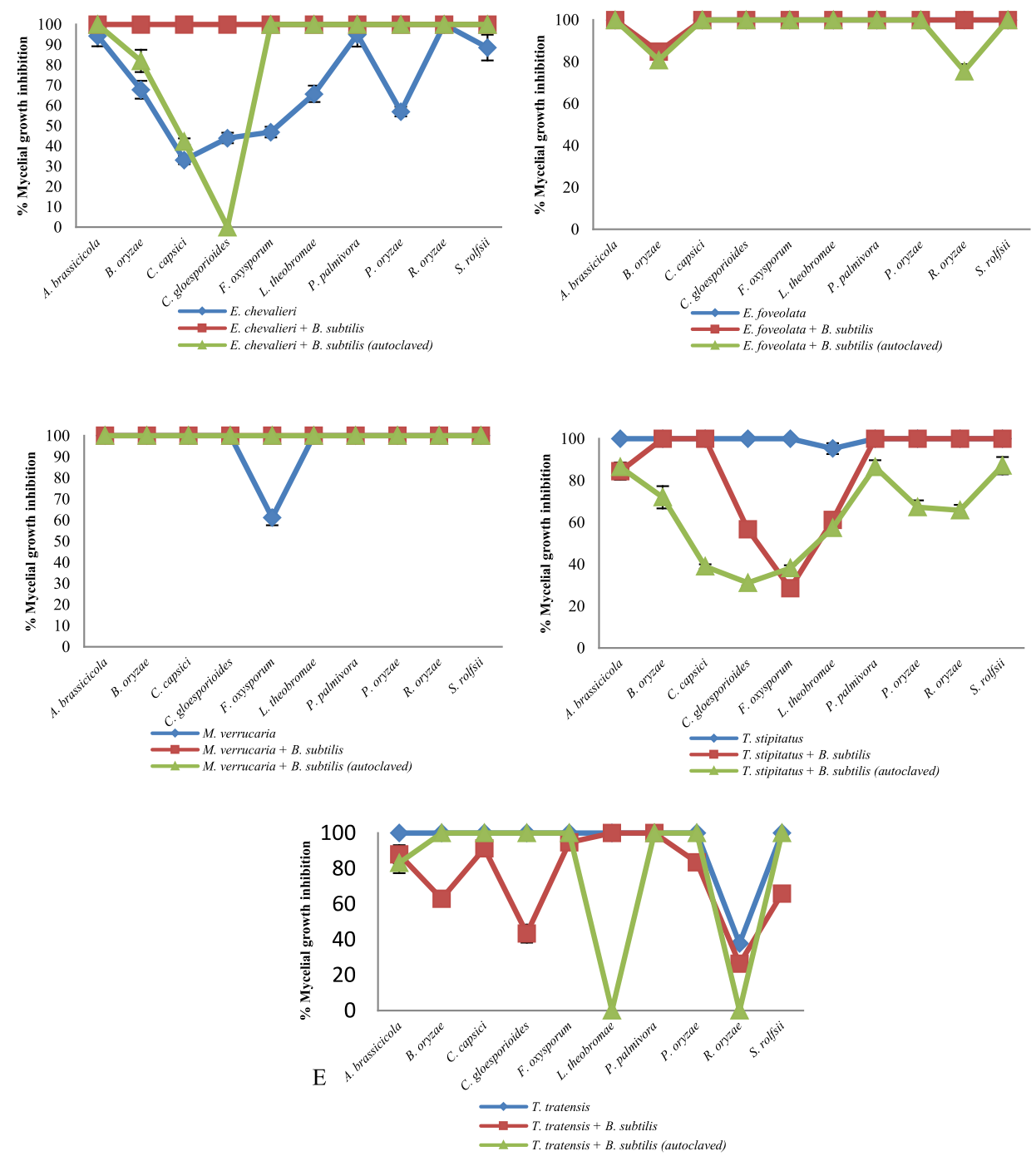

Fig. 1 Inhibitory effect of crude extracts obtained from marine-derived fungi and co-culturing with $B$. subtilis against plant pathogenic fungi at $10 \mathrm{~g} \mathrm{~L}^{-1}$.
A. Eurotium chevalieri KUFA 0464,
B. Emericella foveolata KUFA 1003
C. Myrothecium verrucaria KUFA 0991,
D. Talaromyces tratensis KUFA 0091
E. Talaromyces stipitatus KUFA 0207 


\section{Talaromyces tratensis (KUFA 0091)}

At $10 \mathrm{~g} \mathrm{~L}^{-1}$ concentration, $T$. tratensis extract displayed potent antifungal activity against all plant pathogens tested except $L$. theobromae and $R$. solani at 10 and $1 \mathrm{~g} \mathrm{~L}^{-1}$, a moderate effect against $B$. oryzae and P. palmivora, causing $57 \%$ of mycelial growth inhibition. The extract from the co-culturing of the fungus with $B$. subtilis displayed lower inhibitory effects against all plant pathogenic fungi except $P$. palmivora and $L$. theobromae than the crude extract of $T$. tratensis solitary culture at $10 \mathrm{~g} \mathrm{~L}^{-1}$ (Fig. 1D). However, at 1 $\mathrm{g} \mathrm{L}^{-1}$, the antagonistic activity from co-culturing crude extract with $B$. subtilis exhibited higher activity against $A$. brassicicola, F. oxysporum, P. palmivora and $L$. theobromae than did $T$. tratensis solitary culture crude extract (Fig. 2D).

Meanwhile, the crude extract obtained from the co-culturing of the fungus with autoclaved B. subtilis showed similar inhibition against plant pathogenic fungi tested when compared with the effect $T$. tratensis solitary culture crude extract.
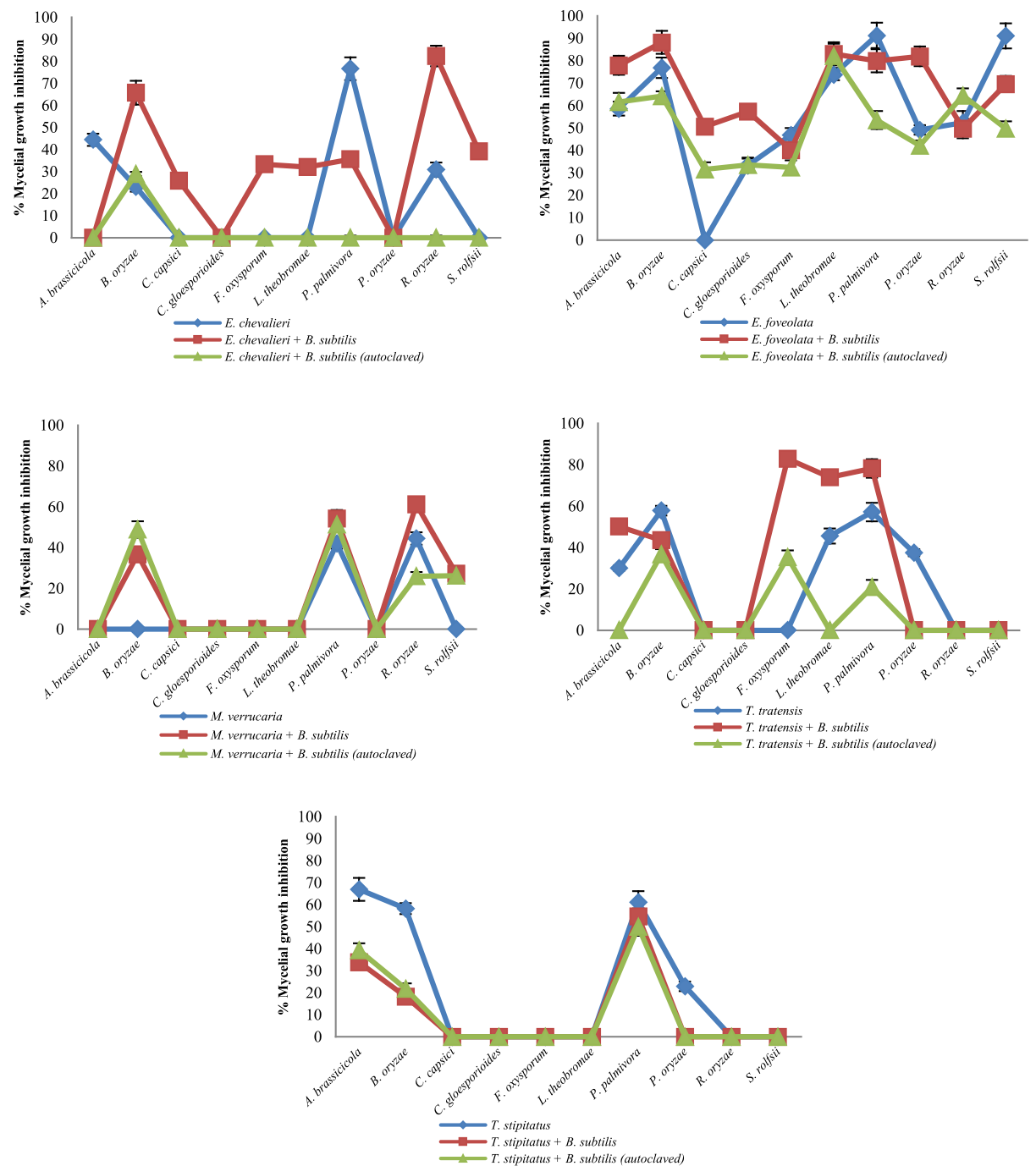

Fig. 2 Inhibitory effect of crude extracts obtained from marine-derived fungi and co-culturing with $B$. subtilis against plant pathogenic fungi at $1 \mathrm{~g} \mathrm{~L}^{-1}$.
A. Eurotium chevalieri KUFA 0464,
B. Emericella foveolata KUFA 1003
C. Myrothecium verrucaria KUFA 0991,
D. Talaromyces tratensis KUFA 0091
E. Talaromyces stipitatus KUFA 0207 
However, at $1 \mathrm{~g} \mathrm{~L}^{-1}$, the crude extract from the co-culturing showed significantly lower antifungal activity against $B$. oryzae, $L$. theobromae and $P$. palmivora than that $T$. tratensis solitary culture crude extract (Fig. 2D).

\section{Talaromyces stipitatus (KUFA 0207)}

At the highest concentration tested, $T$. stipitatus crude extract exerted great antagonistic activity against plant pathogenic fungi tested except for $L$. theobromae and $R$. oryzae at $10 \mathrm{~g} \mathrm{~L}^{-1}$ (Fig. 1E). Meanwhile, at $1 \mathrm{~g} \mathrm{~L}^{-1}$, the crude extract displayed a moderate antifungal activity against $A$. brassicicola, $B$. oryzae, and $P$. palmivora resulting in 58.22-66.94\% mycelial growth inhibition (Fig. $2 \mathrm{E})$. However, the effectiveness of crude extracts from the co-culturing of the fungus with either live or autoclaved $B$. subtilis resulted in reduced antifungal activity against plant pathogenic fungi. The extract from co-culturing of the fungus with $B$. subtilis displayed lower mycelial growth inhibition of $A$. brassicicola, C. gloeosporioides, F. oxysporum and $L$. theobromae than did T. stipitatus solitary culture crude extract at $10 \mathrm{~g} \mathrm{~L}^{-1}$ (Fig. 1E). Likewise, the activity of the extract from co-culturing of the $T$. stipitatus and autoclaved $B$. subtilis exhibited lower antifungal effect against all plant pathogenic fungi than $T$. stipitatus solitary culture crude extract at all concentrations tested.

\section{DISCUSSION}

During the past decade, co-culturing has shown to be a successful method to induce microbial communications that can stimulate the silent pathways resulting in enhancement of metabolites and production of new compounds (Ola et al., 2013; Netzker et al., 2015; Zhang et al., 2017). Hence, we have applied this method to determine the silent antagonistic activity of five marine-derived fungi on mycelial growth of plant pathogenic fungi by co-cultivation with a marinederived bacterium, $B$. subtilis.

The results in this study exhibited that the crude extract from solitary culture of $T$. tratensis exerted the best antifungal activity against the tested plant pathogens followed by $E$. foveolata, $M$. verrucaria, T. stipitatus, and E. chevalieri, respectively. The results were in accordance with many previous reports which found that many species belonging to genus Talaromyces acted as potent antagonists against various plant diseases such as T. falvus, T. trachyspermus, T. tratensis and T. wortmannii (Naraghi et al., 2012; Kakvan et al., 2013; Dethoup et al., 2015; Bahramian et al., 2016). Recently, T. tratensis was reported as a potent antagonist against rice diseases even in planta (Dethoup et al., 2018). However, the antagonistic activities of $T$. stipitatus and $E$. foveolata against plant pathogenic fungi have not previously been reported.

The co-culturing of a fungus and a bacterium has been investigated for determining the chemical production dynamics in several fungi and might lead exploration of novel antimicrobial compounds against pathogens (Kamdem et al., 2018; Qadir et al., 2018; Abdel-Wahab et al., 2019) However, the results obtained from this study showed the extracts from co-culturing of marinederived fungi with live or autoclaved $B$. subtilis resulted in positive, negative and even no effect on antifungal activities against plant pathogens in vitro. Moreover, the inhibitory effect of the co-culture extracts was dependent on the plant pathogen and the concentration. The co-culturing extracts of the fungi with live $B$. subtilis resulted in increased antifungal activity of $E$. chevalieri and $E$. foveolata extracts but decreased the effects of $T$. tratensis and $T$. stipitatus extracts against the plant pathogens tested. These findings are consistent with results of previous studies, although cocultivation may lead to enhancement of known metabolites and production of new compounds, not all of the detected compounds showed potent antimicrobial activities.

The only report of a positive effect due to the co-culturing of a fungus and a bacterium is that of Ola et al., (2017). The authors found that the co-culturing of the fungal endophyte, Fusarium tricinctum with a bacterium, $B$. subtilis enhancing the production of secondary metabolites, of which four compounds and three new natural products. Three of the isolated metabolites showed strong antibacterial activity on B. subtilis, E. faecalis, S. aureus and S. pneumonia.

A significant positive effect of the cocultivating between a marine bacterium and fungus in this study was observed in the coculturing of $E$. chevalieri and $B$. subtilis, which led to complete mycelial growth inhibition of all of the plant pathogens whereas the extract from E. chevalieri solitary culture displayed mycelial 
growth inhibition ranging from $33.11-100 \%$ at 10 $\mathrm{g} \mathrm{L}^{-1}$.

In contrast, Wakefield et al., (2017) reported that the co-culture of Aspergillus fumigatus with Streptomyces leeuwenhoekii, a hyper-arid desert bacterium led to the production of new metabolites as well as induced the amount of known compounds in extract of axenic culture but no antimicrobial activities were reported. Similarly, many investigations have reported that the induce metabolites even novel compounds through co-cultivation of fungal strains and $B$. subtilis did not show increased antifungal activity against human pathogens tested (Akone et al., 2016; Liu et al., 2017; Kamdem et al., 2018).

Meanwhile, the co-culturing of marinederived fungi with autoclaved $B$. subtilis resulted in decreased antifungal activity of $E$. foveolata, $T$. stipitatus and $T$. tratensis but slightly increased activity of E. chevalieri. The co-cultivating of marine-derived fungi with either live autoclaved $B$. subtilis had no effect on antagonistic activity of M. verrucaria. Ancheeva et al., (2017) is the only study reporting the effect of the co-culturing of a fungus with an autoclaved bacterium. These authors found that the co-culture of Chaetomium $\mathrm{sp}$. with autoclaved Pseudomonas aeruginosa led to increase production of fungal metabolites. However, the isolated compounds from the cocultivation did not show antimicrobial activity.

Although, co-culturing of a fungus and a bacterium may lead to enhance chemical production, the effect of this on increasing antibiosis is still in doubt. However, the microbial interaction will lead to antibiosis production for resources competition (Netzker et al., 2018; Qadir et al., 2018). Hence, many researchers have also evaluated the effect of co-culturing between fungi with plant pathogens. Oppong-Danquah et al., (2018) reported the effects of co-culturing marine fungi with phytopathogenic bacteria (Pseudomonas syringae) and fungi (Magnaporthe oryzae and Botrytis cinerea) on agar plates. They found that the co-cultivation of the fungi with plant pathogens tested did not show significant increase in antifungal activity of the marine fungi on plant pathogens although the overall chemical richness was increased in all co-cultures. However, Serrano et al., (2017) reported the increasing antifungal activities and new metabolites from the co-culture extract of Botrytis cinerea with three phytopathogens including $C$. acutatum, $F$. proliferatum and $M$. grisea. They found that the co-cultivation induced antifungal activities and that the new metabolites were only observed in the extracts from the co-cultures.

The effects of crude extract from the cocultivation of a marine fungus with autoclaved $B$. subtilis in this study, showed a significant decrease in the antagonistic activity of marine fungi against plant pathogens. Moreover, the crude extract from the co-cultivation of a marine fungus with autoclaved $B$. subtilis showed lower antifungal activity than that of the crude extract from the co-culturing of a marine-derived fungus with $B$. subtilis. These results indicate that the use of the dead bacterium resulted in reduced antagonistic activity of marine-derived fungi and hence is not a promising approach to induce antagonistic activity of fungi.

In conclusion, the results from this study showed co-culturing with a marine bacterium, $B$. subtilis had positive, negative, or no effect on the antifungal activity of the marine fungi. Meanwhile, the co-culturing with autoclaved $B$. subtilis significantly reduced the antagonistic activity of the tested marine-derived fungi. To the best of our knowledge, this is the first report of the effects of five marine fungi with $B$. subtilis on antagonistic activity against plant pathogenic fungi.

\section{ACKNOWLEDGEMENTS}

We would like to thank the Graduate School of Kasetsart University and the Kasetsart University Research and Development Institute for financially supported in this study.

\section{CONFLICT OF INTEREST}

The authors declare that there is no conflict of interest.

\section{AUTHORS' CONTRIBUTION}

All authors designed the experiments. $U$. M. performed the experiments. T. D. prepared the manuscript and analysed the data. All authors read and approved the manuscript.

\section{FUNDING}

This work was supported by the Graduate School of Kasetsart University (2558) and the 
Kasetsart University Research and Development Institute (39.60)

\section{ETHICS STATEMENT}

This article does not contain any studies with human participants or animals performed by any of the authors.

\section{DATA AVAILABILITY}

All datasets generated or analysed during this study are included in the manuscript.

\section{REFERENCES}

1. Abdel-Wahab NM, Scharf S, Ozkaya FC, et al. Induction of secondary metabolites from the marine-derived fungus Aspergillus versicolor through co-cultivation with Bacillus subtilis. Planta Med. 2019;85(6):503-512. https://doi.org/10.1055/a-0835-2332

2. Akone $\mathrm{SH}$, Mandi A, Kurtan T, et al. Inducing secondary metabolite production by the endophytic fungus Chaetomium sp. through fungal-bacterial co-culture and epigenetic modification. Tetrahedron. 2016;72:6340-6347. https://doi.org/10.1016/j. tet.2016.08.022

3. Ancheeva E, Kuppers L, Akone SH, et al. Expanding the metabolic profile of the fungus Chaetomium sp. through co-culture with autoclaved Pseudomonas aeruginosa. Eur J Org Chem. 2017;22:3256-3264. https://doi.org/10.1002/ejoc.201700288

4. Bahramian D, Naraghi L, Heydari A. Effectiveness of the chemical stabilizers of Talaromyces flavus in biological control of tomato and greenhouse cucumber vascular wilt disease. J Plant Prot Res. 2016;56:291-297. https://doi.org/10.1515/jppr-2016-0045

5. Brasil VLM, Pinto MBR, Bonan RF, Kowalski LP, Perez DED. Pesticides as risk factors for head and neck cancer: A review. J Oral Pathol Med. 2018;47(7):641651. https://doi.org/10.1111/jop.12701

6. Buttachon S, May Zin WWW, Dethoup T, et al. Secondary metabolites from the culture of the marine sponge-associated fungi Talaromyces tratensis and Sporidesmium circinophorum. Planta Med. 2016;82(910):888-896. https://doi.org/10.1055/s-0042-103687

7. Dethoup T, Chaopongpang S, Kijjoa A. Aspergillus similanensis sp.nov. from a marine sponge in Thailand. Mycotaxon. 2016;131(1):7-15. https://doi. org/10.5248/131.7

8. Dethoup $T$, Kaewsalong N, Songkumorn P, Jantasorn A. Potential of a marine-derived species, Talaromyces tratensis KUFA 0091 against rice diseases. Biol Control. 2018;119:1-6. https://doi.org/10.1016/j. biocontrol.2017.11.008

9. Dethoup T, Kumla D, Kijjoa A. Mycocidal activity of crude extracts of marine-derived beneficial fungi against plant pathogenic fungi. J Biopest. 2015;8:107115.

10. El-Mougy MS, Abdel-Kader MM. Bio and fungicide alternatives treatments for suppressing faba bean rust disease under natural field conditions. Biosci Res.

\section{8;15(2):1415-1423.}

11. Ghorchiani M, Etesami H, Alikhani HA. Improvement of growth and yield of maize under water stress by co-inoculating an arbuscular mycorrhizal fungus and a plant growth promoting rhizobacterium together with phosphate fertilizers. Agric Ecosyst Environ. 2018;258:59-70. https://doi.org/10.1016/j. agee.2018.02.016

12. Holka M. Environmental impact assessment of chemical plant protection in intensive crop production. JCEA. 2017;18 (3):529-541. https://doi.org/10.5513/ JCEA01/18.3.1926

13. Kakvan N, Heydari A, Zamanizadeh HR, Rezaee S, Naraghi L. Development of new bioformulations using Trichoderma and Talaromyces fungal antagonists for biological control of sugar beet damping-off disease. Crop Prot. 2013;53:80-84. https://doi.org/10.1016/j. cropro.2013.06.009

14. Kamdem RST, Wang $\mathrm{H}$, Wafo $\mathrm{P}$, et al. Induction of new metabolites from the endophytic fungus Bionectria sp. through bacterial co-culture. Fitoterapia. 2018;124:132-136. https://doi.org/10.1016/j. fitote.2017.10.021

15. Kumla D, Aung TS, Buttachon S, et al.A new dihydrochromone dimer and other secondary metabolites from cultures of the marine spongeassociated fungi Neosartorya fennelliae KUFA 0811 and Neosartorya tsunodae KUFC 9213. Mar Drugs. 2017;15(12):375. https://doi.org/10.3390/ md15120375

16. Kumla D, Dethoup T, Buttachon S, Singburaudom $N$, Silva AMS, Kijjoa A. Spiculisporic acid E, a new spiculisporic acid derivatives from the marine-sponge associated fungus Talaromyces trachyspermus (KUFA 0021). Nat Prod Commun. 2014;9:1147-1150. https:// doi.org/10.1177/1934578X1400900822

17. Liu LM, Liang MQ, Li L, et al. Synergistic effects of the combined application of Bacillus sublitis $\mathrm{H} 158$ and strobilurins for rice sheath blight control. Biol Control. 2018;117:182-187. https://doi.org/10.1016/j. biocontrol.2017.11.011

18. Liu S, Dai HF, Heering C, et al. Inducing new secondary metabolites through co-cultivation of the fungus Pestalotiopsis sp. with the bacterium Bacillus subtilis. Tetrahedron Lett. 2017;58(3):257-261. https://doi. org/10.1016/j.tetlet.2016.12.026

19. Manilal A, Sabarathnam B, Kiran GS, Sujith S, Shakir C, Selvin J. Antagonistic potentials of marine sponge associated fungi Aspergillus clavatus MFD15. Asian J Med Sci. 2010;2:195-200.

20. Moussa M, Ebrahim W, Kalscheuer R, Liu Z, Proksch P. Co-culture of the bacterium Pseudomonas aeruginosa with the fungus Fusarium tricinctum induces bacterial antifungal and quorum sensing signaling molecules. Phytochem Lett. 2020;36:37-41. https://doi. org/10.1016/j.phytol.2020.01.013

21. Murray MG, Thompson WF. Rapid isolation of high molecular weight plant DNA. Nucleic Acids Res. 1980;8(19):4321-4325. https://doi.org/10.1093/ nar/8.19.4321

22. Naraghi L, Heydari A, Rezaee S, Razavi M. Biocontrol agent Talaromyces flavus stimulates the growth of 
cotton and potato. J Plant Growth Regul. 2012;31:471477. https://doi.org/10.1007/s00344-011-9256-2

23. Netzker T, Fischer J, Weber J, et al. Microbial communication leading to the activation of silent fungal secondary metabolites gene clusters. Front Microbiol. 2015;299. https://doi.org/10.3389/ fmicb.2015.00299

24. Netzker T, Flak M, Krespach MKC, et al. Microbial interactions trigger the production of antibiotics. Curr Opin Microbiol. 2018;45:117-123. https://doi. org/10.1016/j.mib.2018.04.002

25. Ola ARB, Thomy D, Lai D, Brotz-Oesterhelt H, Proksch P. Inducing secondary metabolite production by the endophytic fungus Fusarium tricinctum through coculture with Bacillus subtilis. J Nat Prod. 2013;76:2094-2099. https://doi.org/10.1021/ np400589h

26. Oppong-Danquah E, Parrot D, Blumel M, Labes A, Tasdemir D. Molecular networking-based metabolome and bioactivity analyses of marine-adapted fungi co-cultivated with phytopathogens. Front Microbiol. 2018;9:2072. https://doi.org/10.3389/ fmicb.2018.02072

27. Qadir F, Shariq M, Ahmed A, Sohail M. Evaluation of a yeast co-culture for cellulose and xylanase production under solid state fermentation of sugarcane bagasse using multivariate approach. Ind Crops Prod. 2018;123:407-415. https://doi.org/10.1016/j. indcrop.2018.07.021

28. Sanger F, Nicklen S, Coulson AR. DNA sequencing with chain-terminating inhibitors. Proc Natl Acad Sci. 1977;74(12):5463-5467. https://doi.org/10.1073/ pnas.74.12.5463

29. Serrano R, Gonzalez-Menenlez V, Rodriquez L, Martin $\mathrm{J}$, Tormo J R, Genilloud O. Co-culturing of fungal strains against Botrytis cinerea as a model for the induction of chemical diversity and therapeutic agents. Front Microbiol. 2017;8:649. https://doi.org/10.3389/ fmicb.2017.00649

30. Shen S, Li W, Wang J. Antimicrobial and antitumor activities of crude secondary metabolites from a marine fungus Penicillium oxalicum 0312F. Afr J Microbiol Res. 2014;8:1480-1485. https://doi. org/10.5897/AJMR2013.6559

31. Shtark OY, Borisov AY, Zhukov VA, Tikhonovich IA. Mutually beneficial legume symbioses with soil microbials and their potential for plant production. Symbiosis. 2012;58 (1-3):51-62. https://doi. org/10.1007/s13199-013-0226-2

32. Suasa-ard S, Eakjamnong W, Dethoup T. A novel biological control agent against postharvest mango disease caused by Lasiodioplodia theobromae. Eur J Plant Pathol. 2019;155 (2):583-592. https://doi. org/10.1007/s10658-019-01794-z
33. Rizzati V, Briand O, Guillou H, Gamet-Payrastre L. Effects of pesticide mixtures in human and animal models: an update of the recent literature. Chem-Biol Interact. 2016;254:231-246. https://doi.org/10.1016/j. cbi.2016.06.003

34. Rongbian WEI, Fuchao LI, Song R, Song QIN. Comparison of two marine sponge-associated Penicillium strains DQ25 and SC10: differences in secondary metabolites and their bioactivities. Ann Microbiol. 2009;59:579-585. https://doi.org/10.1007/ BF03175149

35. Terao D, Nechet KD, Ponte MS, Maia ADN, Anjos VDD, Halfeld-Vieira BD. Physical postharvest treatments combined with antagonistic yeast on the control of orange green mold. Sci Hort. 2017;224:317-323. https://doi.org/10.1016/j.scienta.2017.06.038

36. Tomm HA, Ucciferri L, Ross AC. Advances in microbial culturing conditions to activate silent biosynthetic gene clusters for novel metabolite production. J Ind Microbiol Biot. 2019;46(9-10):1381-1400. https://doi. org/10.1007/s10295-019-02198-y

37. Turull M, Komarova T, Noller B, Fontas $\mathrm{C}$, Diez $\mathrm{S}$. Evaluation of mercury in a freshwater environment impacted by an organomercury fungicide using diffusive gradient in thin films. Sci Total Environ. 2018;621:1475-1484. https://doi.org/10.1016/j. scitotenv.2017.10.081

38. Wakefield J, Hassan HM, Jaspars M, Ebel R, Rateb ME. Dual induction of new microbial secondary metabolites by fungal bacterial co-cultivation. Front Microbiol. 2017;8: 1284. https://doi.org/10.3389/ fmicb.2017.01284

39. Weisburg WG, Barns SM, Pelletier DA, Lane DJ. 16S ribosomal DNA amplification for phylogenetic study. J Bacteriol. 1991;173:697-703. https://doi.org/10.1128/ JB.173.2.697-703.1991

40. White TJ, Bruns T, Lee S, Taylor J. 38 Amplification and direct sequencing of fungal ribosomal RNA genes for phylogenetics, 1990; pp. 315-322, In Innis MA, Gelfand DH, Sninsky JJ, White TJ (eds.), PCR protocols: a guide to methods and applications, Academic Press, New York. https://doi.org/10.1016/B978-0-12-3721808.50042-1

41. Zhang G, Wang F, Qin J, et al. Efficacy assessment of antifungal metabolites from Chaetomium globosum No. 05, a new biocontrol agent, against Setosphaeria turcica. Biol Control. 2013;64:90-98. https://doi. org/10.1016/j.biocontrol.2012.10.005

42. Zhang LH, Niaz SI, Khan D, et al. Induction of diverse bioactive secondary metabolites from the mangrove endophytic fungus Trichoderma sp. (strain 307) by co-cultivation with Acinetobacter johnsonii (strain B2). Mar Drugs. 2017;15(2):35. https://doi.org/10.3390/ md15020035. https://doi.org/10.3390/md15020035 